\title{
Modeling cation exchange capacity and soil water holding capacity from basic soil properties
}

\section{Idowu Ezekiel Olorunfemi ${ }^{\text {a,* }}$, Johnson Toyin Fasinmirin a , Adefemi Samuel Ojo ${ }^{b}$}

a Department of Agricultural and Environmental Engineering, Federal University of Technology, Akure, Nigeria b Department of Agricultural and Bio - Environmental Engineering, Lagos State Polytechnic, Lagos, Nigeria

\section{Article Info}

Received : 26.01.2016 Accepted : 14.03.2016

\begin{abstract}
Cation exchange capacity (CEC) is a good indicator of soil productivity and is useful for making recommendations of phosphorus, potassium, and magnesium for soils of different textures. Soil water holding capacity (SWHC) defines the ability of a soil to hold water at a particular time of the season. This research predicted CEC and SWHC of soils using pedotransfer models developed (using Minitab 17 statistical software) from basic soil properties (Sand(S), Clay(C), soil pH, soil organic carbon (SOC)) and verify the model by comparing the relationship between measured and estimated (obtained by PTFs) CEC and SWHC in the Forest Vegetative Zone of Nigeria. For this study, a total of 105 sampling points in 35 different locations were sampled in the study areas. Three sampling points were randomly selected per location and three undisturbed samples were collected at each sampling point. The results showed success in predicting CEC and SWHC from basic soil properties. In this study, five linear regression models for predicting soil CEC and seven linear regression models for predicting SWHC from some soil physical and chemical properties were suggested. Model 5 [CEC $=-13.93+2.645 \mathrm{pH}$ $+0.0446 \mathrm{C}(\%)+2.267 \mathrm{SOC}(\%)]$ was best for predicting CEC while model 12 [SWHC $(\%)=36.0-0.215 \mathrm{~S}(\%)+0.113 \mathrm{C}(\%)+10.36 \mathrm{SOC}(\%)]$ is the most acceptable model for predicting SWHC.
\end{abstract}

Keywords: Cation exchange capacity, soil water holding capacity, pedotransfer function, multiple linear regression, Nigeria.

(C) 2016 Federation of Eurasian Soil Science Societies. All rights reserved

\section{Introduction}

Cation exchange capacity (CEC) of a soil is a measurement of its ability to bind or hold exchangeable cations. In other words, it is a measure of the number of negatively-charged binding sites in soil (Rashidi and Seilsepour, 2008). The cation exchange capacity of a soil represents the total amount of exchangeable cations that a soil can retain. Cation exchange capacity helps characterize the soil type under consideration. For example, because organic matter in soil is a major source of negative electrostatic sites there is a strong correlation between CEC values, and amount of organic matter present in soil (Harada and Inoko, 1975). The CEC results provided insight into the type of soil, as well as secondary information for use in formulating a fertilizer programme. Characterization of soils' CEC is useful for making recommendations for the amounts of phosphorus, potassium, and magnesium for soils of different textures.

Soil water holding capacity (SWHC) is the amount of water retained in capillary spaces of soil after gravitational water loss into deeper layers of the soil (Senjobi and Ogunkunle, 2011). Soil water storage available for plant use is generally calculated as being between field capacity and wilting point, as water

\footnotetext{
${ }^{*}$ Corresponding author.

Department of Agricultural and Environmental Engineering, Federal University of Technology, Akure, Nigeria

Tel.: +234 7037986945

E-mail address: olorunfemiidowu@gmail.com

e-ISSN: 2147-4249 DOI: 10.18393 /ejss.2016.4.266-274
} 
contents higher than, while usually plant-available, are generally not sustained for long times except under specific circumstances (Sumner, 2000). The estimation of SWHC of a soil is of great value to practical agriculture, because it provides a simple means of determining moisture contents required for soils, for good plant growth, and infiltration of water into soil which is another important dynamic flow processes in the hydrological cycle (Viji and Rajesh, 2011). Knowing the soil water storage capacity allows the irrigator to determine how much water to apply at one time and how long to wait between each irrigation (Olorunfemi, 2014). Soil water holding capacity of any soil is determined by its texture, structure, and organic matter content. Soil texture influences the water retention capabilities of soils of different locations, as soils with high clay percentage or both (high clay percentage and organic matter content) tends to have high SWHC (Senjobi and Ogunkunle, 2011). Soil texture and crop rooting depth affect total amount of water stored in the soil within the plant's rooting zone. Therefore, characterizing SWHC of different locations is about defining the ability of a soil to hold water by soil and for use by a particular crop at a particular time of the season.

Cation exchange capacity and soil water holding capacity can be measured by laboratory experiments. Despite the progress made in measuring soil properties directly, laboratory analysis of some soil physical and chemical properties is still laborious and expensive to obtain. For example, CEC is often determined using laborious and time consuming laboratory tests. Also, soil properties can be highly variable spatially and temporally and measuring these properties is time consuming and difficult, but it may be more suitable, economical and essential to derive relationships that link the basic soil properties to the functional soil properties that are more difficult to measure. Recently, indirect estimation of these functional properties from widely available or more easily measured basic soil properties like; sand (S), silt (Si), clay (C), bulk density (BD), soil organic carbon (SOC) and soil organic matter (SOM) that contribute to the functional properties using pedotransfer functions (PTFs) has received considerable attention (Wösten et al., 1995; Minasny and McBratney, 2002; Minasny et al., 2004, Amini et al., 2005). According to Martel et al. (1978), Manrique et al. (1991), and Rashidi and Seilsepour (2008), soil components known to contribute to soil CEC are clay and organic matter, and to a lesser extent, silt. Several researchers: Yuan et al. 1967 (for sandy soils in Florida); Drake and Motto 1982 (for New Jersey soils); Sahrawat 1983 (for some Philippine soils) and Bell and van Keulen 1995 (for four soils in Mexico) have attempted to predict CEC from clay and organic carbon contents, while and Rashidi and Seilsepour (2008) predicted CEC from organic carbon alone for soils in Varamin, Iran, using multiple regression. Also, Krogh et al. (2000) suggested an equation based on silt, clay, organic carbon, and $\mathrm{pH}$. In most of these models, CEC is assumed to be a linear function of soil organic matter and clay content (Breeuwsma et al., 1986; McBratney et al., 2002).

This study will determine relationships linking basic soil properties to CEC and SWHC thereby providing quick and easy determination of CEC and SWHC. The knowledge of these properties and process leads to better predictions of agricultural soil water management systems. In the light of the above, objectives of this research were to predict CEC and SWHC of soils using pedotransfer models developed from basic soil properties. Then, verify the model by comparing the relationship between measured and estimated (obtained by PTF) values in the forest vegetative zone of Nigeria.

\section{Material and Methods}

\section{Experimental site and procedure Experimental site}

The study was conducted in Ekiti State in the forest vegetative zone of Nigeria (Figure1). Ekiti State is located between Latitudes $7^{\circ} 15^{\prime}$ to $8^{\circ} 5^{\prime} \mathrm{N}$ and Longitude $4^{\circ} 45^{\prime}$ to $5^{\circ} 45^{\prime} \mathrm{E}$ and occupies an area of about 6 , $353 \mathrm{~km}^{2}$ (EKSG, 2009). The State is mainly an upland zone, rising over $250 \mathrm{~m}$ above sea level. The highest contour line of $540 \mathrm{~m}$ above sea level is found around the North Eastern limit of the state (Simon-Oke and Jegede, 2012). It lies on an area underlain by metamorphic rock and is potentially rich in mineral deposits which include granite, kaolin, columbite, channockete, iron ore, barite, aquamine, gemstone, phosphate, limestone, gold among others largely deposited in different towns and villages within the State. The State enjoys tropical climate with two distinct seasons. These are the rainy season (April - October) and dry season (November - March). The air temperature ranges between $21^{\circ}$ and $28^{\circ}$ with high humidity. Ekiti State has a total annual rainfall of about $1400 \mathrm{~mm}$ with an average of about 112 rainy days per year (Adebayo, 1993). The dominant soils in Ekiti state are Egbeda series and Iwo series (Syrnth and Montgomery, 1962). Under the FAO/UNESCO classification, they are Orthic and Plinthic Luvisols, respectively (FAO, 1998). The vegetation of Ekiti State is guinea forest with its attendant climate, flora and fauna (EKSG, 2009). 


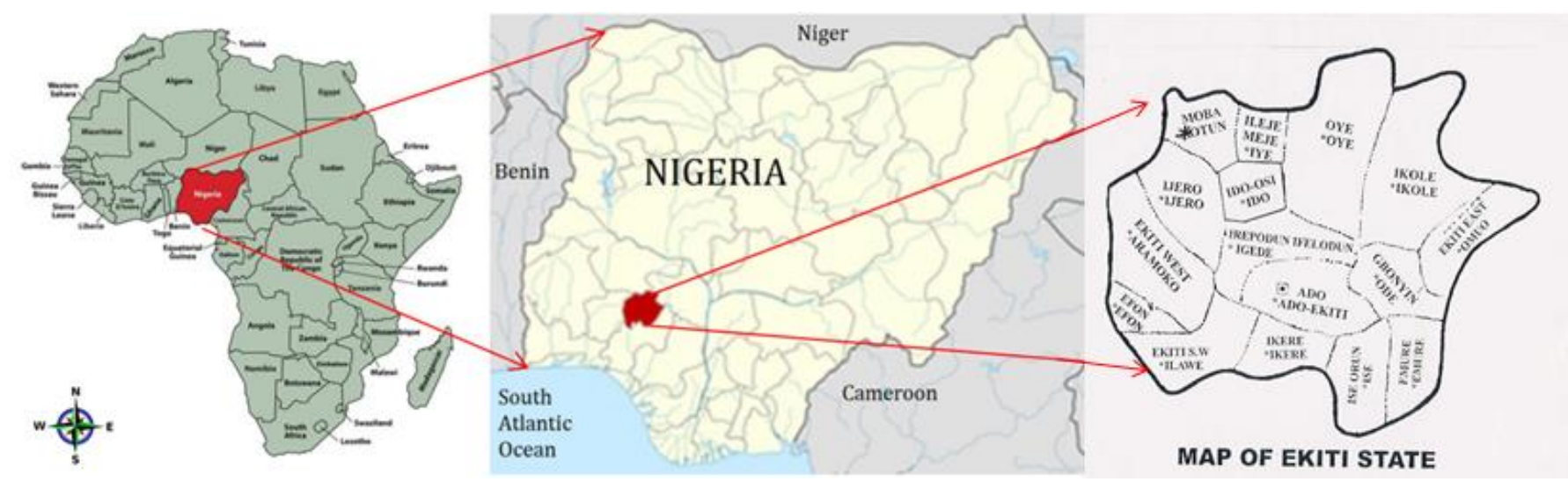

Figure 1. Location of the study area

\section{Experimental procedure}

Soil sampling and field experiments were carried out across 35 different locations (communities) in Ekiti State. Undisturbed soil samples from the topsoil (Horizon A) were collected from each experimental site using stainless steel cylindrical cores. Soil samples were collected in depths of 0 to $30 \mathrm{~cm}$. Three sampling points were randomly selected per location and three undisturbed samples were collected at each sampling point. In general, 105 soil samples were taken randomly at the different locations in Ekiti State. Soil samples collected were packed in plastic bags, and transferred to the laboratory. The samples were allowed to dry in the open air until reaching friability.

\section{Measurements}

\section{Physico-chemical characterization of soils}

Chemical characterization of the collected soil samples include the analysis of SOM, SOC, CEC at pH of 7.0, base saturation, $\mathrm{Al}^{3+}$ saturation and soil $\mathrm{pH}$. Physical characterization consisted of particle size analysis, SWHC determination. The organic carbon was determined using Walkley - Black wet oxidation procedure and soil organic matter content was determined from organic carbon (Nelson and Sommers, 1996). The cation exchange capacity (CEC) at $\mathrm{pH} 7.0$ was determined following the procedure compiled and described by Reeuwijk (2002). The exchangeable potassium $\left(\mathrm{K}^{+}\right)$and sodium $\left(\mathrm{Na}^{+}\right)$was extracted with $\mathrm{HCl}$ solution and their levels determined by flame photometry (Vogelmann et al., 2010) and exchangeable magnesium $\left(\mathrm{Mg}^{2+}\right)$ and calcium $\left(\mathrm{Ca}^{2+}\right)$ by atomic absorption spectrophotometer (Senjobi and Ogunkunle, 2010). Soil pH was determined in distilled water using the $\mathrm{pH}$ meter with water ratio of 1:2. Soil particle sizes were determined using the hydrometer method described in Agbede and Ojeniyi (2009). Soil water holding capacity was determined following the method described by Ibitoye (2006).

\section{Statistical analysis}

Soil properties were subjected to statistical analysis to determine the mean, standard deviation, coefficient of variation among soil samples from different locations. Each soil property was compared using Pearson correlation coefficient at 1 and 5\% significant levels and the existence of inter-relationships between data set was tested by linear correlation using Minitab 17 statistical software. To predict the cation exchange capacity (CEC) of soil, pedotransfer (PTF) functions, which are multiple regression equations, among soil properties were obtained using the Minitab 17 statistical software. A paired samples t-test and the mean difference confidence interval approach were used to compare predicted and measured values of soil CEC and SWHC. Descriptive statistics such as minimum and maximum value, arithmetic mean value, standard deviation (SD), and coefficient of variation (CV) were calculated to help in providing explanations and assessing dispersion of the variables. Measure of Dispersion tells us about the variation of the data set.

Statistics such as Correlation Coefficient (R), Root Mean Square Error (RMSE), Mean Absolute Error (MAE), and Relative Error (RE) were calculated using equation (1), (2), (3), and (4) respectively, where n represents the number of instances presented to the model and $\mathrm{O}_{\mathrm{i}}$ and $\mathrm{P}_{\mathrm{i}}$ represents measured and predicted, and $\mathrm{O}_{\text {ave }}$ and $\mathrm{P}_{\mathrm{ave}}$ represents mean values of measured and predicted respectively. 


$$
\begin{array}{r}
R=\left[\frac{\sum_{\mathrm{i}=1}^{\mathrm{n}}\left(\mathrm{O}_{\mathrm{i}}-\mathrm{o}_{\mathrm{ave}}\right)\left(\mathrm{p}_{\mathrm{i}}-\mathrm{p}_{\mathrm{ave}}\right)}{\sqrt{\sum_{\mathrm{i}=1}^{\mathrm{n}}\left(\mathrm{O}_{\mathrm{i}}-\mathrm{O}_{\mathrm{ave}}\right)^{2}\left(\mathrm{p}_{\mathrm{i}}-\mathrm{p}_{\mathrm{ave}}\right)^{2}}}\right] \\
R M S E=\left[\frac{\sum_{\mathrm{i}=1}^{\mathrm{n}}\left(\mathrm{p}_{\mathrm{i}}-\mathrm{o}_{\mathrm{i}}\right)^{2}}{\mathrm{n}}\right]^{1 / 2} \\
M A E=\sum_{\mathrm{i}=1}^{\mathrm{n}}\left[\left|\mathrm{P}_{\mathrm{i}}-\mathrm{o}_{\mathrm{i}}\right| / \mathrm{n}\right] \\
R E=\left(\mathrm{MAE} / \mathrm{O}_{\mathrm{ave}}\right) 100
\end{array}
$$

\section{Results and Discussion}

\section{Physical and chemical properties of sampled soils}

Descriptive statistics of some physical and chemical properties of the soils used in this study were given in Table 1. Cation exchange capacity of all 35 sampled soils ranged from $3.43 \mathrm{cmol}_{c} \mathrm{~kg}^{-1}$ to $11.97 \mathrm{cmol}_{\mathrm{c}} \mathrm{kg}^{-1}$ with an average value of $6.53 \mathrm{cmol}_{c .} \mathrm{kg}^{-1} \pm 2.01$. Cation exchange capacity values showed that the distribution is positively and moderately skewed with a skewness coefficient of 0.78 while values of the coefficient of kurtosis of 0.16 suggested a platykurtic behavior in their distribution. The soil water holding capacity (SWHC) ranged from $29.27 \%$ to $71.83 \%$ for all soil samples in the 35 locations with an average value of 45 $\%$, standard deviation of 3.05 and coefficient of variation of $70 \%$. The skewness coefficient (1.28) of the SWHC of the sampled locations reveals a distribution that is positive and highly skewed while the kurtosis coefficient (2.57) showed that the distribution is platykurtic. Skewness and kurtosis reveal the direction of variation of the data set. It also informs about the normality of the data set.

Table 1. Descriptive statistics of physical and chemical properties of sampled soils

\begin{tabular}{lcccccccc}
\hline $\begin{array}{l}\text { Statistics/Soil } \\
\text { Properties }\end{array}$ & $\begin{array}{c}\text { Sand } \\
(\%)\end{array}$ & $\begin{array}{c}\text { Silt } \\
(\%)\end{array}$ & $\begin{array}{c}\text { Clay } \\
(\%)\end{array}$ & Soil pH & $\begin{array}{c}\text { SOC } \\
(\%)\end{array}$ & $\begin{array}{c}\text { SOM } \\
(\%)\end{array}$ & $\begin{array}{c}\text { SWHC } \\
(\%)\end{array}$ & $\begin{array}{c}\text { CEC } \\
\left(\mathrm{cmol}^{2} \mathrm{~kg}^{-1}\right)\end{array}$ \\
\hline Minimum & 24.00 & 4.00 & 20.00 & 4.95 & 0.88 & 1.52 & 29.27 & 3.43 \\
Maximum & 64.00 & 32.00 & 56.00 & 6.36 & 2.36 & 4.07 & 71.83 & 11.97 \\
Arithmetic Mean & 44.57 & 21.37 & 34.06 & 5.95 & 1.42 & 2.46 & 45.00 & 6.53 \\
Standard Deviation & 9.85 & 6.23 & 9.54 & 0.32 & 0.38 & 0.66 & 8.53 & 2.01 \\
Coeff. of Variation & 0.22 & 0.29 & 0.28 & 0.05 & 0.27 & 0.27 & 18.96 & 0.31 \\
Skewness & -0.53 & -0.73 & 0.47 & -0.65 & 0.72 & 0.65 & 0.26 & 0.77 \\
Kurtosis & -0.31 & 0.51 & -0.70 & -0.23 & 0.06 & -0.06 & 1.50 & 0.16 \\
\hline
\end{tabular}

Relations between CEC, SWHC, and some soil properties

Cation exchange capacity showed positive correlation with soil pH $\left(\mathrm{r}=0.441^{* *}\right)$, SOC $\left(\mathrm{r}=0.580^{* *}\right)$, SOM $(\mathrm{r}=$ $\left.0.572^{* *}\right)$, SWHC $\left(\mathrm{r}=0.580^{* *}\right)$, and clay content $\left(\mathrm{r}=0.356^{*}\right)$ at $p \leq 0.01$ and $p \leq 0.05$ respectively amongst all the soil samples in the 35 experimental locations (Table 2). It was observed that soils with high organic matter content and clay particles demonstrated high CEC values which is due to the fact that the cationexchange capacity (CEC) of soils is mainly due to clay minerals and soil organic matter (Martel et al. 1978; Manrique et al. 1991; Harada and Inoko, 1975) and silt to a lesser extent (Rashidi and Seilsepour, 2008). Organic matter in soil is a major source of negative electrostatic sites; therefore there is a strong correlation between CEC value and amount of organic matter present in the soil. The research findings were also in agreement with the works of Bayer and Bertol (1999); Vogelmann et al., (2010) and Fasinmirin and Olorunfemi (2012) who reported that soil samples with higher values of CEC were found to have high levels of organic matter and $\mathrm{pH}$. Also in any given soil, the number of exchange sites is dependent on the soil $\mathrm{pH}$; type, size and amount of clay; and amount and source of the organic material (Kamprath and Welch 1962; Miller 1970; Parfitt et al. 1995; Rashidi and Seilsepour, 2008). Soil water holding capacity correlated positively with clay content $(\mathrm{r}=0.539, p \leq 0.01)$ and negatively with sand content $(\mathrm{r}=-0.517, p \leq 0.01)$. 
Results of the correlation analysis between SWHC (\%) and SOM (\%) revealed a significant and positive relationship $(r=0.584, N=35, p \leq 0.01)$. Senjobi and Ogunkunle (2011) reported that soils having high proportion of sands are associated with low SWHC. The result also shows that if clay and organic matter contents increase, water holding capacity of the soil also increases (FAO, 2005). This observation correlated with the findings of Senjobi and Ogunkunle (2011) who further stated that water holding capacity of soils increase with increase in clay content of soils in their study to assess the extent to which different land use types influences land degradation and productivity in Ogun State, Nigeria. SWHC of the soils resulted from fine texture nature of the soils.

Table 2. Pearson correlations coefficient (r) among various soil properties

\begin{tabular}{|c|c|c|c|c|c|c|c|c|}
\hline & $\mathrm{pH}$ & Sand & Silt & Clay & SOC & SOM & SWHC & $\overline{\mathrm{CEC}}$ \\
\hline $\mathrm{pH}$ & 1 & & & & & & & \\
\hline Sand & $.088^{\mathrm{ns}}$ & 1 & & & & & & \\
\hline Silt & $.065^{\mathrm{ns}}$ & $-.366^{*}$ & 1 & & & & & \\
\hline Clay & $-.134^{\mathrm{ns}}$ & $-.794^{* *}$ & $-.275^{\mathrm{ns}}$ & 1 & & & & \\
\hline SOC & $.128^{\mathrm{ns}}$ & $-.363^{*}$ & $-.140^{\mathrm{ns}}$ & $.467^{* *}$ & 1 & & & \\
\hline SOM & $.139 \mathrm{~ns}$ & $-.339^{*}$ & $-.137 \mathrm{~ns}$ & $.440^{* *}$ & $.993^{* *}$ & 1 & & \\
\hline WHC & $.152^{\mathrm{ns}}$ & $-.517^{* *}$ & $-.008^{\mathrm{ns}}$ & $.539^{* *}$ & $.610^{* *}$ & $.584^{* *}$ & 1 & \\
\hline CEC & $.441^{* *}$ & $-.281^{\mathrm{ns}}$ & $-.101^{\mathrm{ns}}$ & $.356^{*}$ & $.580^{* *}$ & $.572^{* *}$ & $.569^{* *}$ & 1 \\
\hline
\end{tabular}

ns, not significant.

${ }^{* *}$ Correlation is significant at the 0.01 level, *Correlation is significant at the 0.05 level

\section{Prediction of soil cation exchange capacity (CEC) using pedotransfer models}

Pedotransfer models to predict CEC value of soils were developed regarding the results of correlation analysis. The following models for CEC were obtained from multiple regressions on data (Model 1-5) The pedotransfer models, which were developed using some soil physical properties, to predict cation exchange capacity (CEC) were statistically significant at $1 \%$ probability level.

1) $\mathrm{CEC}=2.17+3.072 \mathrm{SOC}(\%)$

2) $\mathrm{CEC}=1.77+0.0230 \mathrm{C}(\%)+2.802 \mathrm{SOC}(\%)$

3) $\mathrm{CEC}=-11.62+2.379 \mathrm{pH}+2.819 \mathrm{SOC}(\%)$

4) $\mathrm{CEC}=-15.37+3.173 \mathrm{pH}+0.0890 \mathrm{C}(\%)$

5) $\mathrm{CEC}=-13.93+2.645 \mathrm{pH}+0.0446 \mathrm{C}(\%)+2.267 \mathrm{SOC}(\%)$

Model 5 was the best model for predicting CEC with $\mathrm{R}=0.711$, $\mathrm{RMSE}=1.39, \mathrm{MAE}=1.16$ and $\mathrm{RE}=17.77$ (Table 3). Table 4 shows the result of Paired Samples Test used to compare the measured and predicted CEC values. Using an alpha level of 0.05 , a dependent-samples $t$ test was conducted to evaluate whether CEC values determined using two methods of laboratory test and pedotransfer function differed significantly. The results indicated that the CEC values determined using two methods of laboratory test $(\mathrm{M}=6.53, \mathrm{SD}=$ 2.01) was not significantly different from the CEC values predicted using the second method $(\mathrm{M}=6.53, \mathrm{SD}=$ 1.43), with $\mathrm{t}(34)=2.83, \mathrm{p}=1.00$

The 95\% confidence interval for the mean difference between the two methods of determination was -0.48 to 0.48 . Comparison of observed versus predicted values of CEC obtained from the models (1 - 5) were depicted in Figure 2 that indicates good match as a 1.0:1.0 scale and 45-degree angle with vertical.

Table 3. Summary of statistics of various models of soil cation exchange capacity (CEC)

\begin{tabular}{ccccc}
\hline & \multicolumn{4}{c}{ Statistics Parameters } \\
\cline { 2 - 5 } Models & $\mathrm{R}$ & RMSE & MAE & RE \\
\hline 1 & 0.580 & 1.61 & 1.28 & 19.54 \\
2 & 0.588 & 1.60 & 1.23 & 18.79 \\
3 & 0.687 & 1.44 & 1.22 & 18.74 \\
4 & 0.608 & 1.57 & 1.29 & 19.72 \\
5 & 0.711 & 1.39 & 1.16 & 17.77 \\
\hline
\end{tabular}

R: Correlation Coefficient; RMSE: Root Mean Square Error; MAE: Mean Absolute Error; RE: Relative Error. 

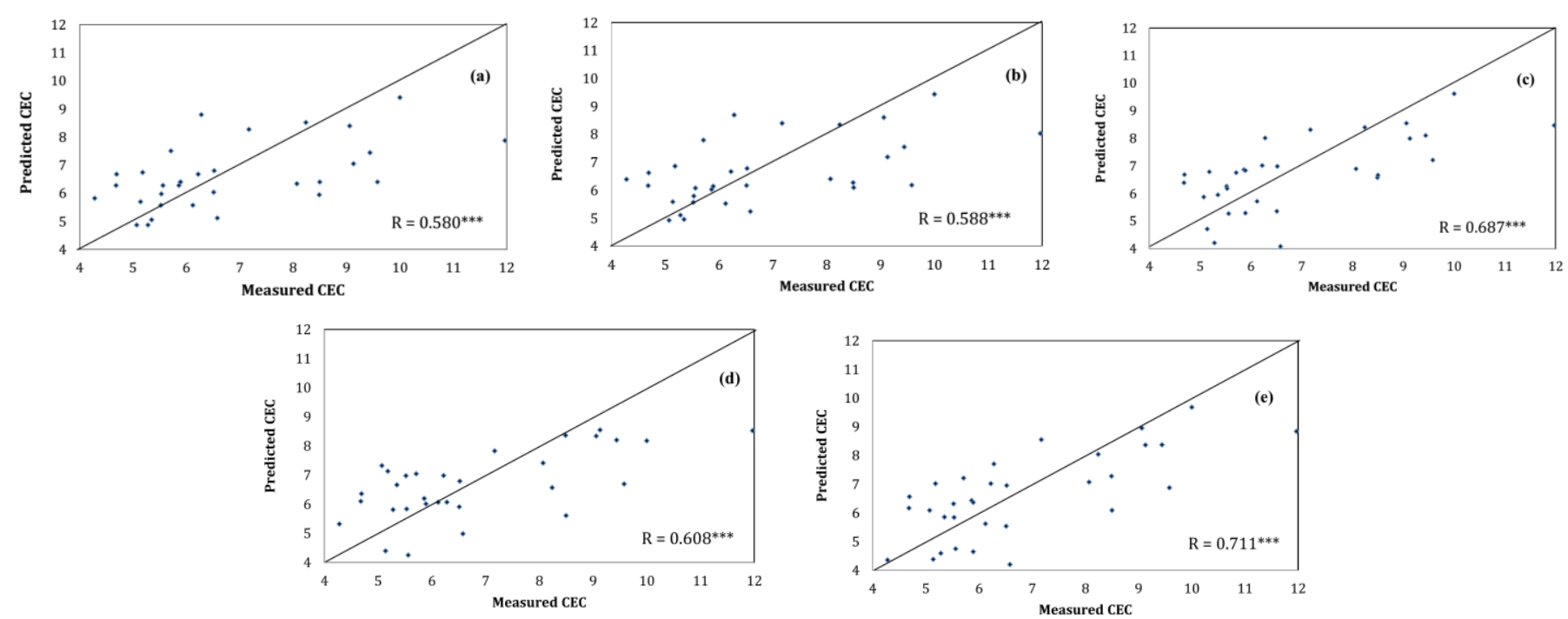

Figure 2. Comparison of measured CEC and predicted CEC for (a) model 1, (b) model 2, (c) model 3, (d) model 4, (e) model 5 with the line of equality (1.0: 1.0) (***Significant at the 0.001 level).

Table 4. Paired Samples Test analyses on comparing soil CEC determination methods

\begin{tabular}{|c|c|c|c|c|c|c|c|c|}
\hline & \multicolumn{5}{|c|}{ Paired differences } & \multirow[b]{3}{*}{$\mathrm{t}$} & \multirow[b]{3}{*}{$\mathrm{df}$} & \multirow{3}{*}{$\begin{array}{c}\text { Sig. } \\
\text { (2-tailed) }\end{array}$} \\
\hline & \multirow[b]{2}{*}{ Mean } & \multirow[b]{2}{*}{ SD. } & \multirow[b]{2}{*}{ SEM } & \multicolumn{2}{|c|}{$\begin{array}{l}95 \% \text { confidence interval } \\
\text { of the difference }\end{array}$} & & & \\
\hline & & & & Lower & Upper & & & \\
\hline Model No. 1 Measured CEC - Predicted CEC & .00 & 1.64 & .27662 & -.56215 & .56215 & .000 & 34 & 1.000 \\
\hline Model No. 2 Measured CEC - Predicted CEC & .00 & 1.62 & .27467 & -.55819 & .55819 & .000 & 34 & 1.000 \\
\hline Model No. 3 Measured CEC - Predicted CEC & .00 & 1.46 & .24646 & -.50087 & .50087 & .000 & 34 & 1.000 \\
\hline Model No. 4 Measured CEC - Predicted CEC & .00 & 1.59 & .26944 & -.54758 & .54758 & .000 & 34 & 1.000 \\
\hline Model No. 5 Measured CEC - Predicted CEC & .00 & 1.41 & .23853 & -.48475 & .48475 & .000 & 34 & 1.000 \\
\hline
\end{tabular}

SD; Standard Deviation, SEM; Standard Error of the Mean

\section{Prediction of soil water holding capacity (SWHC) using Pedotransfer models}

Pedotransfer models to predict SWHC values of soils were developed regarding the results of correlation analysis (Model 6-12)

6) $\mathrm{SWHC}(\%)=64.93-0.447 \mathrm{~S}(\%)$

7) $\mathrm{SWHC}(\%)=28.57+0.482 \mathrm{C}(\%)$

8) $\operatorname{SWHC}(\%)=25.52+13.72$ SOC $(\%)$

9) $\operatorname{SWHC}(\%)=43.6-0.207 \mathrm{~S}(\%)+0.312 \mathrm{C}(\%)$

10) SWHC $(\%)=42.59-0.294 \mathrm{~S}(\%)+10.94$ SOC $(\%)$

11) SWHC $(\%)=20.46+0.291 \mathrm{C}(\%)+10.30 \mathrm{SOC}(\%)$

12) SWHC $(\%)=36.0-0.215 \mathrm{~S}(\%)+0.113 \mathrm{C}(\%)+10.36 \mathrm{SOC}(\%)$

Likewise, predicted SWHC values by the models and values determined by laboratory methods were not statistically significantly different from each other. The test statistics for model 12 which is the most acceptable model was based on the mean difference between paired values of the measured and predicted SWHC (0.00) relative to the SE (Standart Error) of paired difference between sampled means (0.24). Results of the paired-samples t-test (Table 5) show that mean SWHC of the measured SWHC (M $=44.50, \mathrm{SD}=8.53$ ) did not differ from predicted SWHC $(\mathrm{M}=44.50, \mathrm{SD}=5.89)$ at the 0.05 level $(\mathrm{t}=0.00, \mathrm{df}=34, \mathrm{n}=35, \mathrm{p}=1.00$, $95 \% \mathrm{CI}$ for mean difference -2.12 to 2.12 ). Findings therefore suggest that use of pedotransfer models could be reliable for quick assessment of soil water holding capacity and cation exchange capacity of soils with 
95\% confidence limit. Comparison of observed vs. predicted values of CEC obtained from the models (6 - 12) has been depicted in Figure 3 that indicates good match as a 1.0:1.0 scale and 45-degree angle with vertical.

Table 5. Summary of Statistics of Various Models of Soil water holding capacity (SWHC)

\begin{tabular}{ccccc}
\hline & \multicolumn{4}{c}{ Statistics Parameters } \\
\cline { 2 - 5 } Models & $\mathrm{R}$ & RMSE & MAE & RE \\
\hline 1 & 0.517 & 7.20 & 5.27 & 11.70 \\
2 & 0.539 & 7.08 & 5.39 & 11.98 \\
3 & 0.610 & 6.66 & 5.17 & 11.49 \\
4 & 0.558 & 6.97 & 5.16 & 11.47 \\
5 & 0.687 & 6.11 & 4.53 & 10.06 \\
6 & 0.674 & 6.21 & 4.92 & 10.94 \\
7 & 0.691 & 6.08 & 4.60 & 10.21 \\
\hline
\end{tabular}

R: Correlation Coefficient; RMSE: Root Mean Square Error; MAE: Mean Absolute Error, RE: Relative Error

Table 6. Paired Samples Test analyses on comparing soil SWHC determination methods

\begin{tabular}{|c|c|c|c|c|c|c|c|c|}
\hline & \multicolumn{5}{|c|}{ Paired Differences } & \multirow[b]{3}{*}{$\mathrm{t}$} & \multirow[b]{3}{*}{$\mathrm{df}$} & \multirow{3}{*}{$\begin{array}{c}\text { Sig. } \\
\text { (2-tailed) }\end{array}$} \\
\hline & \multirow[b]{2}{*}{ Mean } & \multirow[b]{2}{*}{ SD } & \multirow[b]{2}{*}{ SEM } & \multicolumn{2}{|c|}{$\begin{array}{c}95 \% \text { confidence interval } \\
\text { of the difference }\end{array}$} & & & \\
\hline & & & & Lower & Upper & & & \\
\hline Model No. 1 Measured WHC - Predicted WHC & .00 & 7.30 & 1.23 & -2.51 & 2.51 & .000 & 34 & 1.000 \\
\hline Model No. 2 Measured WHC - Predicted WHC & .00 & 7.18 & 1.21 & -2.47 & 2.47 & .000 & 34 & 1.000 \\
\hline Model No. 3 Measured WHC - Predicted WHC & .00 & 6.76 & 1.14 & -2.32 & 2.32 & .000 & 34 & 1.000 \\
\hline Model No. 4 Measured WHC - Predicted WHC & .00 & 7.08 & 1.20 & -2.43 & 2.43 & .000 & 34 & 1.000 \\
\hline Model No. 5 Measured WHC - Predicted WHC & .00 & 6.20 & 1.05 & -2.13 & 2.13 & .000 & 34 & 1.000 \\
\hline Model No. 6 Measured WHC - Predicted WHC & .00 & 6.30 & 1.06 & -2.16 & 2.16 & .000 & 34 & 1.000 \\
\hline Model No. 7 Measured WHC-Predicted WHC & .00 & 6.17 & 1.04 & -2.12 & 2.12 & .000 & 34 & 1.000 \\
\hline
\end{tabular}

SD; Standard Deviation, SEM; Standard Error of the Mean
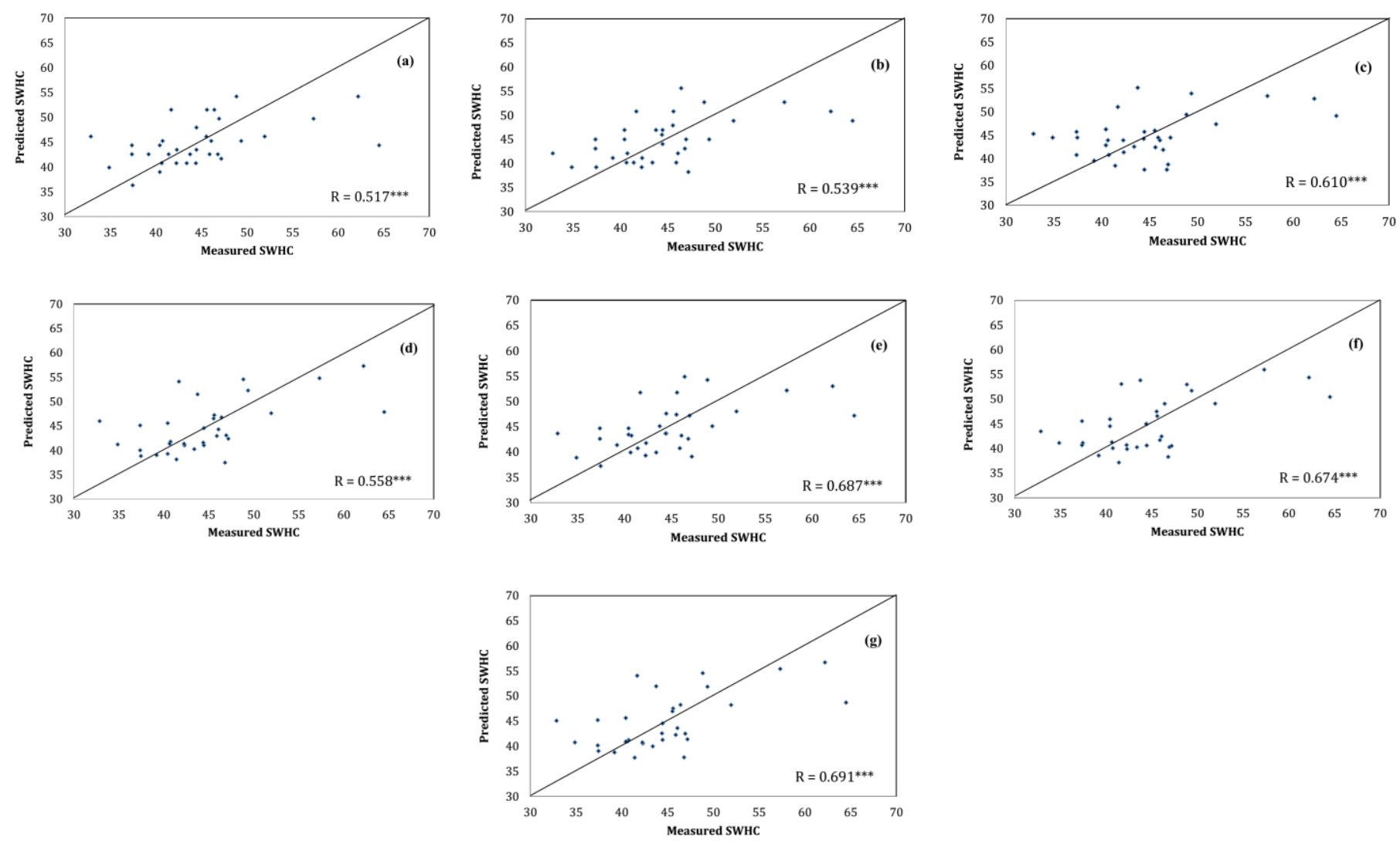

Figure 3. Comparison of measured SWHC and predicted SWHC for (a) model 1, (b) model 2, (c) model 3, (d) model 4, (e) model 5, (f) model 6, (g) model 7 with the line of equality (1.0: 1.0) (***Significant at the 0.001 level). 


\section{Conclusion}

Pedotransfer models were successfully used to predict CEC and SWHC using multiple linear regression methods from basic soil properties. The paired samples $\mathrm{t}$ - test results indicated that the difference between predicted and measured values of the soil CEC and SWHC were not statistically significant using an alpha level of 0.05 . Therefore, by using pedotransfer models, one can derive relationships that link basic soil properties to the functional soil properties that are more expensive and difficult to measure. This will result in quicker access to more expensive soil and environmental functional properties. The knowledge of these SWHC and process leads to better predictions and management of irrigation and water management systems. Likewise, CEC is a good indicator of soil productivity and a major criterion used when making soil fertilizer recommendations. Convenience in determining these properties will result in better farm management and greater agricultural productivity.

\section{References}

Adebayo, W.O. 1993. Weather and climate. In: Ado-Ekiti region; A geographical analysis and master plan. Ebisemiju, F.S. (Ed.). Lagos, Alpha Prints, pp.11- 14.

Agbede, T.M., Ojeniyi, S.O., 2009. Tillage and poultry manure effects on soil fertility and sorghum yield in southwestern Nigeria. Soil Tillage Research 104(1): 74-81.

Amini, M., Abbaspour, K. C., Khademi, H., Fathianpour, N., Afyuni, M., Schulin, R., 2005. Neural network models to predict cation exchange capacity in arid regions of Iran. European Journal of Soil Science, 56: 551-559.

Bayer, C., Bertol, I., 1999. Soil chemical characteristics of a humic cambisol as affected by tillage systems in southern brazil, with emphasis on soil organic matter. Revista Brasileira de Ciência do Solo 23(3): 687-694. [in Portuguese]

Bell, M.A., van Keulen, J., 1995. Soil pedotransfer functions for four Mexican soils. Soil Science Society of America Journal 59(3): 865-871.

Blake, G.R., Hartge, K.H., 1986. Bulk density. In: Methods of Soil Analysis: Part 1. Physical and mineralogical methods, $2^{\text {nd }}$ Edition. Klute, A. (Ed.), ASA-SSSA, Madison, WI, USA. pp. 363-375.

Breeuwsma, A., Wösten, J.H.M., Vleeshouwer, J.J., van Slobbe, A.M., Bouma, J., 1986. Derivation of land qualities to assess environmental problems from soil surveys. Soil Science Society of America Journal 50(1): 186-190.

Danielson, R.E., Sutherland, P.L., 1986. Porosity. In: Methods of Soil Analysis: Part 1. Physical and mineralogical methods, 2nd Edition. Klute, A. (Ed.), ASA-SSSA, Madison, WI, USA. pp. 443-461.

Drake, E.H., Motto, H.L., 1982. An analysis of the effect of clay and organic matter content on the cation exchange capacity of New Jersey soils. Soil Science 133(5): 281-288.

EKSG, 2009. Ekiti State Government. Diagnostic Survey Report. UNAAB-IFSERAR. Available at: http://www.unaab.edu.ng/attachments/EkitiState.pdf [access date: 10.12.2015]

FAO, 1998. World reference base for soil resources. Food and Agriculture Organization of The United Nations. FAO World Soil Resources Reports No. 84. Rome, Italy

FA0. 2005. The importance of soil organic matter. Key to drought-resistant soil and sustained food production. Food and Agriculture Organization of The United Nations. FAO Soils Bulletin No. 80. Rome, Italy

Fasinmirin, J.T., Olorunfemi, I.E., 2012. Comparison of hydraulic conductivity of soils of the forest vegetative zone of Nigeria. Applied Tropical Agriculture 17(1): 64 - 77.

Harada, Y., Inoko, A., 1975. Cation-exchange properties of soil organic matter. I. Effects of conditions for the measurement on cation-exchange capacity values of humic acid preparations. Soil Science and Plant Nutrition 21(4): 361-369.

Ibitoye, A.A., 2006. Laboratory manual on basic soil analysis. $2^{\text {nd }}$ Edition, Foladave Publishing Company, Akure, Ondo State, Nigeria. 82 pp.

Kamprath, E.J., Welch, C.D., 1962. Retention and cation-exchange properties of organic matter in coastal plain soils. Soil Science Society of America Journal 26(3): 263-265.

Krogh, L., Breuning-Madsen, H., Greve, M.H., 2000. Cation exchange capacity pedotransfer function for Danish soils. Acta Agriculturae Scandinavica, Section B-Soil \& Plant Science 50: 1-12.

Li, Y.Y., Shao, M.A., 2006. Change of soil physical properties under long-term natural vegetation restoration in the Loess Plateau of China. Journal of Arid Environments 64(1): 77-96.

Manrique, L.A., Jones, C.A., Dyke, P.T., 1991. Predicting cation-exchange capacity from soil physical and chemical properties. Soil Science Society of America Journal 55(3): 787- 794.

Martel Y.A., Kimpe C.R.D., Laverdiere, M.R. 1978. Cation-exchange capacity of clay-rich soils in relation to organic matter, mineral composition and surface area. Soil Science Society of America Journal 42(5): 764-767.

McBratney, A.B., Minasny, B., Cattle, S.R., Vervoort, R.W. 2002. From pedotransfer functions to soil inference systems. Geoderma 109(1-2): 41-73. 
Miller, W.F., 1970. Inter-regional predictability of cation- exchange capacity by multiple regression. Plant and Soil 33(1): 721-725.

Minasny, B., Hopmans, J.W., Harter, T., Eching, S.O., Tuli, A., Denton, M.A., 2004. Neural networks prediction of soil hydraulic functions for alluvial soils using multistep outflow data. Soil Science Society of America Journal 68(2): 417-429.

Minasny, B., McBratney, A.B., 2002. The Neuro-m method for fitting neural network parametric pedotransfer functions. Soil Science Society of America Journal 66(2): 352-361.

Nelson, D.W., Sommers, L.E., 1996. Total carbon, organic carbon and organic matter. In: Methods of Soil Analysis, Part 3. Chemical Methods. Sparks, D.L. (Ed.),2 ${ }^{\text {nd }}$ ed., SSSA-ASA. Madison, Wisconsin, USA. pp. 961-1010.

Olorunfemi, I. E. 2014. Occurrence, causes, and impacts of hydrophobicity on soils of different land uses in Ekiti State. (M.Eng Thesis). Federal University of Technology, Akure, Nigeria.

Parfitt R.L., Giltrap D.J., Whitton J.S. 1995. Contribution of organic matter and clay minerals to the cation exchange capacity of soils. Communications in Soil Science and Plant Analysis 26(9-10): 1343-1355.

Price, K., Jackson, C.R., Parker, A.J., 2010. Variation of surficial soil hydraulic properties across land uses in the southern Blue Ridge Mountains, North Carolina, USA. Journal of Hydrology 383(3-4): 256-268.

Reeuwijk, L.P., 2002. Procedures for soil analysis. Technical Paper 9. $6^{\text {th }}$ Edition. International Soil Reference and Information Centre (ISRIC) \& Food and Agricultural Organization of the United Nations (FAO). Wageningen, The Netherlands.

Rashidi, M., Seilsepour, M., 2008. Modeling of soil cation exchange capacity based on soil organic carbon. ARPN Journal of Agricultural and Biological Science 3(4):41-45.

Sahrawat, K.L., 1983. An analysis of the contribution of organic matter and clay to cation exchange capacity of some Philippine soils. Communications in Soil Science and Plant Analysis 14(9): 803-809.

Senjobi, B.A., Ogunkunle, O.A., 2010. Effect of land use on soil degradation and soil productivity decline on alfisols and ultisols in Ogun State in South Western, Nigeria. Agriculturae Conspectus Scientificus 75(1): 9-19.

Senjobi, B.A., Ogunkunle, A.O., 2011. Effect of different land use types and their implications on land degradation and productivity in Ogun State, Nigeria. Journal of Agricultural Biotechnology and Sustainable Development 3(1): 7-18.

Simon-Oke, O.O., Jegede, A.O., 2012. Spatial distribution of micro finance institutions and agricultural development in Ekiti State, Nigeria. AFRREV IJAH: An International Journal of Arts and Humanities 1(3): 258-269.

Smyth, A.J., Montgomery, R.F., 1962. Soil and Land Use in Central Western Nigeria. Government Printer, Ibadan, p. 265.

Sumner, M.E., 2000. Handbook of soil science. CRC Press, Boca Raton. Washington DC, USA. pp. S591.H23.

Viji, R., Rajesh, P.P., 2011. Assessment of water holding capacity of major soil series of Lalgudi, Trichy, India. Journal of Environmental Research and Development 7(1A)

Vogelmann, E. S., Reichert, J.M., Reinert, D. J. Mentges, M.I., Vieira, D. A., Peixoto de Barros, C. A., Fasinmirin, J.T., 2010. Water repellency in soils of humid subtropical climate of Rio Grande do Sul, Brazil. Soil and Tillage Research 110(1): 126-133.

Wösten, J.H.M., Finke, P.A., Jansen, M.J.W., 1995. Comparison of class and continuous pedotransfer functions to generate soil hydraulic characteristics. Geoderma 66(3-4): 227-237.

Yuan, T.L., Gammon, N., Leighty, R.G., 1967. Relative contribution of organic and clay fractions to cation- exchange capacity of sandy soils from several soil groups. Soil Science 104(2): 123-128.

Zhang, S., Grip, H., Lövdahl, L., 2006. Effect of soil compaction on hydraulic properties of two loess soils in China. Soil and Tillage Research 90(1-2): 117-125. 